\title{
POLITICAL TOURISM
}

Itineraries in Conflict: Israelis, Palestinians, and the Political Lives of Tourism, by Rebecca L. Stein. Durham and London: Duke University Press, 2008. x + 152 pages. Notes to p. 178 . Bibliography to p. 204. Index to p. 219 . $\$ 79.95$ cloth; $\$ 22.95$ paper.

\section{Reviewed by Tom Selwyn}

Itineraries in Conflict: Israelis, Palestinians, and the Political Lives of Tourism makes seminal contributions to at least three distinct anthropological fields: war,

Tom Selwyn is a professorial research associate in the Department of Anthropology at the School of Oriental and African Studies, University of London, where he teaches the anthropology of tourism. 
nationalism, and tourism. By interlocking these topics within a single and tightly organized narrative about imagining, remembering, and traveling within the land and landscapes of Palestine, Israel, and the wider region, Rebecca L. Stein succeeds in leaving the reader with the sense that the scope of each has been considerably expanded.

The book covers, in the main, the period between the signing of the Oslo accords in 1993 and the second intifada in 2000 , although necessary contextual references are also made to events that both preceded (such as early pre-state journeys by Jewish immigrants to the region) and followed (such as the bombing of a Sinai hotel in 2004) these dates.

Stein, a cultural anthropologist, opens with an account of visits to the "peace tent" in the Palestinian village of "Arraba. The tent, originally erected for a family party, was refashioned to cater commercially for a new interest in Palestinian culture by Jewish Israeli tourists following the 1993 Oslo accords. It was a space in which these tourists were able to make contact with what they could imagine was (with its Bedouin coffee pots, carpets, etc.) "authentic Arab culture," whilst remaining comfortably outside any real and/or substantive political reconfiguration in the region. Although in this sense, the peace tent itself constituted more fantasy than fundamental change, Stein states that her work concerns "ways that Israeli tourist practices have participated in reformulating the Israeli nation-state amidst trans-national political processes in the Middle-East" (p. 2 ). We are thus guided through these practices, from the pre-state Zionist tiyoulim (tours) of the region; to the touring practices of the period between the establishment of the state and the 1967 war, largely carried out within the post-1948 Israeli state frontiers; to post-1967 travel to the occupied Palestinian territories; and finally to the period after the second intifada when tours beyond the labile borders between Israel and Palestine became more or less off limits once again. The reconstraining of itineraries in this last period both resulted from and symbolically confirmed the fact that "Jewish Israeli society had largely renounced the politics of co-existence, returning to the conflict paradigm that had characterized Israel's relations with neighboring states prior to the onset of regional diplomacy in the 1990s" (p. 150).

All of this underlines the main objective of the book, which is to explore how touring practices throughout the period reflected, and were formed by, the contours that underpinned the imagining of the Israeli nation-state by Jewish Israelis. A consistent theme throughout the book is that Oslo gave rise not only to the notion (held by many Israelis) that coexistence between Israelis and Palestinians and between Israel and neighboring states was possible and achievable, but also that this idea was almost as, if not more, terrifying than the perpetual conflict from which the accords promised deliverance. Back in 1968, the then Israeli minister for tourism had said that "Israelis will visit the pyramids of Egypt and markets of Damascus whilst multitudes of Arab tourists will stream into Israel to visit their holy places and see with their own eyes the foreign Israel that they have learned to hate" (p. 159). As part of the Oslo process in the mid-1990s, an Israeli strategic tourism plan also announced the imminent prospect of Israel becoming the center of " a network of regional contacts: highways, flight paths, seaways, pipelines, indicating that the region's inhabitants would live a life free from obstacles, ostracism, and political coercion" (p. 159). The type of regionalism and globalization presaged by such statements was deeply troubling to many as it disturbed "the mythology of an Israeli nation-state that was secure and homogeneous" and threatened to "expose the fiction of a nation-state that is neitber in nor of the Arab MiddleEast" (p. 152). The fundamental question addressed by the book thus concerns the existential fear among Israel's European elite of how the imagined European nationstate of Israel would, and/or could, survive the truly open borders that regional peace would entail.

With the foregrounding of such issues, the book weaves in and out of ethnographic essays on topics such as the "culinary patriotism" of restaurants in Abu Ghosh and the "consumer co-existence" associated with the efforts of Israeli tourism and architectural experts to stage (for Israeli, European, and American visitors) authentic "Arab" spaces within the interiors of Palestinian villages in Israel, thus shaping what Stein calls a tourist "geography of interiority" (p. 72). 
Itineraries in Conflict is a very carefully written and scholarly work, of interest as much to generalists as to specialists in the subjects and geographical areas covered. Critics might argue that Israeli society is not as homogeneous as the author's account implies, whereas optimists may find comfort in the book's description of routine contemporary journeys by Mizrahi Jews to their former homes in the Middle East. The persistence of such regional tourism might provide a basis from which hopes and expectations about the benefits of regional peace might successfully challenge the darkly pessimistic myths held by some of the Israeli European elite about the connections between open borders and their nation's mortality. 